\title{
Fostering Language Learning in the University EFL Classroom through Literature: A Task-Based Approach'
}

\section{La Literatura en el aprendizaje de inglés como Lengua Extranjera en la Universidad: Un Enfoque basado en Tareas}

\author{
Argemiro Arboleda Arboleda and Angela Yicely Castro Garcés² \\ Universidad del Valle and Universidad del Cauca, Colombia
}

\begin{abstract}
The role of literature as a teaching and learning tool in English as a Foreign Language has long been acknowledged. Literary texts offer teachers opportunities to provide students with authentic materials to heighten their motivation by involving them in challenging Task-Based activities in which they interact with authors and learn about features of these authors' society. The purpose of this research study was to investigate the role of literature as a pedagogical tool in the EFL classroom and see how this can be advantageous in fostering learners' language skills. The sample population encompassed 26 sixth-semester students enrolled in a Reading course who are completing their BA in Foreign Languages at a public University in Colombia. A semi-structured questionnaire and a Reading Guide were designed to elicit information from students who were asked to read an unabridged English language fiction novel. The findings show that the participants' motivation to complete the Task-Based Reading and Writing Project was high and that this had a positive impact on the improvement of their language skills.
\end{abstract}

Keywords. EFL, ESL, Task-Based Approach, Literature, intercultural Communicative Competence

\section{Resumen}

El papel de la literatura como herramienta en la enseñanza y el aprendizaje de lenguas extranjeras ha sido reconocido durante mucho tiempo. Los textos literarios ofrecen oportunidades a los profesores para que mediante el uso de materiales auténticos los estudiantes aumenten su motivación, al involucrarlos en actividades interesantes

1 Received February 4th 2019/ Accepted September $9^{\text {th }} 2019$

2 Argemiro.arboleda@correounivalle.edu.co; angelayicely@gmail.com 
Basadas en Tareas, en las que interactúan con autores y aprenden acerca de la sociedad de dichos escritores. El propósito de esta investigación era indagar acerca del papel de la literatura como herramienta pedagógica en la clase de EFL y ver sus ventajas en el desarrollo de las habilidades lingüísticas de los estudiantes. Los sujetos de estudio fueron 26 estudiantes de sexto semestre de un curso de Lectura de la Licenciatura en Lenguas Extranjeras en una universidad pública, en Colombia. Para recoger la información, se diseñó un cuestionario y una guía de lectura acerca de una novela de ficción en lengua inglesa. Los resultados muestran que la motivación de los estudiantes para completar el Proyecto de Lectura y Escritura basado en Tareas fue alta y que esta influyó positivamente en la mejoría de sus habilidades lingüísticas.

Palabras claves. Inglés como Lengua Extranjera, Inglés como Segunda Lengua, Enfoque Basado en Tareas, Literatura, Competencia Comunicativa Intercultural

\section{Resumo}

O papel da literatura como ferramenta no ensino e a aprendizagem de línguas estrangeiras tem sido reconhecido durante muito tempo. Os textos literários oferecem oportunidades aos professores para que mediante o uso de materiais autênticos os estudantes aumentem a sua motivação, ao envolvê-los em atividades interessantes Baseadas em Tarefas, nas que interatuam com autores e aprendem sobre a sociedade de mencionados escritores. O propósito desta pesquisa era indagar sobre o papel da literatura como ferramenta pedagógica na aula de EFL e ver suas vantagens no desenvolvimento das habilidades linguísticas dos estudantes. Os sujeitos de estudo foram 26 estudantes de sexto semestre de um curso de Leitura da Licenciatura em Línguas Estrangeiras em uma universidade pública, na Colômbia. Para coletar a informação, desenhou-se um questionário e uma guia de leitura sobre uma novela de ficção em língua inglesa. Os resultados mostram que a motivação dos estudantes para completar o Projeto de Leitura e Escritura baseado em Tarefas foi alto e que este influiu positivamente na melhora de suas habilidades linguísticas.

Palavras chaves. Inglês como Língua Estrangeira, Inglês como Segunda Língua, Enfoque Baseado em Tarefas, Literatura, Competência Comunicativa Intercultural 


\section{Introduction}

$\mathrm{T}$ This study originated in our desire to inquire about students' perceptions of the use of literary texts as a pedagogical tool in the EFL classroom. Literature has long been a focus of study at different levels around the world. Yet the interest of Colombian English as Foreign Language (EFL) classroom professionals in using literature as a teaching tool seems to be a relatively new issue, as judged from the scarcity of research studies dealing with it. Different factors may explain this: teachers' notion of literature, teachers' lack of self-confidence in teaching literature, and methodological approaches to teaching literature, among others. Based on our beliefs deeply rooted in our classroom experience, we claim that in spite of any discouraging experience an EFL teacher may have gone through in his attempt to bring literature into his classroom, namely students' low motivation, recitation of book contents at verbatim, and inability to go beyond literal context to make inferences, to build meaning; and what may be worse, student's cutting and pasting other reader's ideas about a given book, couple with rather simplistic questions from the teacher himself, it is still possible to enliven his lessons by engaging students in meaningful tasks. These are designed to establish a fruitful dialogue between writers and language students, a dialogue in which students, as interlocutors, are presented with a wide range of opportunities to learn about authors, their work, and their culture, while immersing themselves in the target language. Thus, the purpose of this research study is to discuss the use of literature as an important vehicle in enhancing EFL learning, particularly in teacher training programs at university level, and point at ways how this can be realized through the design and implementation of task-based tailored activities. To do this, we present relevant research findings dealing with literature in EFL classrooms, look into studies focusing on task-based learning, and rationalize the integration of the two as being complementary in the teaching and learning of a foreign language. This study posed some challenge for the researchers, since in previous class discussions our students admitted not having read a fiction novel completely, nor being given freedom to choose the book they wanted to read, let alone being required to recreate one or more main themes the novel dealt with by expressing themselves aesthetically. Likewise, students felt that they need to spend time in grammar study and in getting familiar with the conventions of academic writing. In this respect, efforts were made to attend to students' needs by planning lessons that addressed their concerns. 


\section{Aim}

The aim of this research study was to delve into the role of literature as a pedagogical tool in the EFL class and see how this can be advantageous in fostering learners' language skills, through the use of literary texts as noninstructed materials.

\section{Review of Literature}

\section{Teacher's notion of Literature}

The interplay between literature and language may not always be acknowledged by EFL teachers as a key factor in language learning. In part, this may be due to the lack of agreement on what is understood by literature. Hence, any attempt to discuss the role of literature in language learning must start by defining the term. The American Heritage Dictionary of the English Language defines literature as "Imaginative or creative writing, especially of recognized artistic value." (2015). Other definitions of literature abound. Savvidou (2004) claims that literature is language, and language can indeed be literary. She is, however, concerned with the way some teachers view literature: “... particularly complex and inaccessible to the foreign language learner" (p. 2). She goes on to contend that these views reflect the historic separation between the study of language and the study of literature and asserts that the use of literary texts can be a powerful pedagogical tool. In this same line of thought, other authors have documented the downplay literature has gone through in language teaching for decades (Collie \& Slater, 1987 \& Short, 1996). Yet, given the fact that literature has proven to be a great resource to go beyond the structural view of language teaching, to build up linguistic as well as cultural competence, additional research continued to be carried out in the field, and works acknowledging the benefits of literature started to appear (Widdowson, 1983; Hill, 1986; Valdes, 1986; Gower \& Pearson, 1986; Collie \& Slater, 1987; Duff \& Maley, 1991, Lazar, 1993).

Motivated by the gains brought about by Literature -- a tool, a resource, or a vehicle, as referred to in different studies--, classroom teachers have successfully come to integrating it in EFL/ ESL contexts, with the certainty that it can be of much help to their students' language learning process.

104 Thus, in the words of Violetta-Irene (2005, p. 74), "Literature in a language classroom provides enough space for the learners to comment, justify and mirror themselves. By using literary texts, the language class can turn out to be lively and motivating." She further indicates ways of using literature in the classroom to help students improve their English language, while describing literature as a field that, although not novel, gives relevance to the literary text as a work of art. 
Additional reasons for using literature in the language classroom are pointed out by Lazar (1993). He believes that when presented as it is, a literary text becomes a valuable educational tool, as it constitutes a rich source to spark motivation, immerse students into another culture, trigger language acquisition, and encourage them to speak up their minds.

As presented here, not only is literature the path through which language students can have access to authentic materials, but it is also a useful tool by means of which they are taken through the wonderful world of different text typologies working at their best. In fact, Collie \& Slater (2005) emphasize the advantages of the literary text in the language classroom given that it is "authentic material ... learners are thus exposed to language that is genuine and undistorted; they gain additional familiarity with many different linguistic uses, forms and conventions of the written mode: with irony, exposition, argument, narration, and so on" (p. 6).

As to the undeniable link between literature and language, Ihejirika (2014) demonstrates ways in which literature can be integrated with language teaching and learning with ESL students. He asserts that "There is a symbiotic relationship between literature and language ... Literature and language are not only intertwined but also inter-related; literature presupposes language because it is with the instrument of language that literature is concretized" (p. 86). This view is echoed by Ayo (2003) who claims that literature is instrumental in helping students grow linguistically, for it presents them with novel reasons to want to read, thus being a medium through which they can improve both their reading and speaking skills.

Valdes (1986) states that literature is a viable component of second language programs at the appropriate level and that one of the major functions of literature is to serve as a medium to transmit the culture of the people who speak the language in which it is written.

Kooy \& Chiu (1998) in their urge to find ways in which they could expose students to literary texts and share their passion for literature with EFL students, who could barely cope with their limited language skills and worried mainly about passing standardized national tests, present literature as a place where language and meaning merge. For them, literature should be considered "not only for its intrinsic worth, but [also] as an integral part of a languagelearning program" (p.79). These studies, then, suggest that teachers integrate literature in their classes and illustrate how beneficial its implementation can be, which is in consonance with our research aims.

Although not widely explored in our local context, studies have been conducted by teacher researchers who have ventured into systematizing and sharing their thoughts in the field. Gomez Rodriguez (2013) encourages the use of multicultural literary texts in the EFL classroom to develop critical 
intercultural communicative competence (ICC), as he is concerned with the main focus on the study of language forms and communicative functions and the lack of inclusion of ICC in the Colombian context. Moreover, Garzon Duarte (2007) presents literary texts as a facilitative tool to develop critical thinking skills in the foreign language classroom in an attempt to take students beyond the structural aspects of the language, exposing them to different worlds and different authors' voices, and providing them with more real communication contexts.

\section{Teachers' lack of self-confidence in teaching literature}

We have already pointed out that literature is frequently associated with complex writing or works that are difficult to understand by foreign language learners. Coupled with this is the belief that only field specialists have the knowledge necessary to teach literature. Although partially true, it is precisely this assumption which deters EFL teachers from venturing into using literature as a powerful tool to enrich and enliven their classrooms. In fact, an EFL teacher may or may not be a literature specialist. Yet, we firmly believe that it is still possible for non-specialists to profit from the array of great literary publications to have their students get a head start in their quest for language learning, by providing them with the type of activities most likely to encourage them to do their best at acquiring and using language for real communication. As understood here, the design and implementation of literary text-based activities do not necessarily have to resemble the ones specifically tailored to meet the needs of students in content-based literature courses. Instead, it is claimed that a more informal teaching approach to teaching literature can be used by EFL teachers, even when they are not experts in the field of literature, provided that they know the target language, like reading literature themselves, and are eager to share their enthusiasm for this magic world with their own students.

\section{The Task-Based Learning Approach}

Task-based learning (TBL) can turn language teaching and learning a social and cultural practice. Several authors (Skehan, 1996, 1998; Willis 1996;

106 Nunan, 2004; Ellis, 2003; \& Willis \& Willis, 2007) have added to consolidating a definition of TBL and have proposed different frameworks that give teachers and learners the opportunity to live and work with the target language in rather dynamic and engaging ways, in which meaning building is vital.

Nunan (2004) highlights how task-based language teaching (TBLT) has permeated educational settings, including its language policies and research agendas. He argues that the focus on tasks acts as both the goal of and the 
vehicle for learning by directly linking classroom learning with communication outside the classroom. This author also establishes a difference between real world and pedagogical tasks - discerning language use inside and outside the classroom. This differentiation is consonant with our own view of the TBA shared here, since the tasks we propose to exploit literary texts take students' language further from the classroom setting. In other words, our vision is truly conveyed by Nunan, as he also believes that "a pedagogical task is a piece of classroom work that involves learners in comprehending, manipulating, producing or interacting in the target language, while their attention is focused on mobilizing their grammatical knowledge in order to express meaning, and in which the intention is to convey rather than to manipulate form" (p. 4). Still another useful definition of task is Ellis' (2003) "a workplan that requires learners to process language pragmatically, in order to achieve an outcome that can be evaluated in terms of whether the correct or appropriate propositional content has been conveyed ... a task is intended to result in language use that bears a resemblance, direct or indirect to the way language is used in the real world"(p.16)

When characterizing the nature of a task, Skehan (1998) speaks of it as having five characteristics: meaning is primary, learners are not given other people's meaning to regurgitate, there is some sort of relationship comparable to real-world activities, task completion has some priority, and the assessment of the task is in terms of the outcome.

Willis (1996) also provides elements to help teachers define classroom tasks. She indicates that there are six main types of task: listing, ordering and sorting, comparing, problem solving, sharing personal experiences, and creative tasks. Her framework presents a practical guide for teachers to include tasks in their classes, which encompasses three phases: the pre-task phase, the task cycle, and the language focus. It is essential to highlight that tasks are learner-centered and have specific learning goals. In addition, having a language focus phase at the end gives students meaningful input. Willis \& Willis (2007) elaborate more on this point as they state that "form-focused teaching will produce language display instead of meaning exchange ... TBLT takes meaning as its starting point" (p. 113-117).

Studies carried out in specific language classroom settings acknowledge the value of this approach for learners' empowerment. For instance, Torres (2014) favors the positive environment that an EFL setting provides for TBL, given authentic material is provided, and an emphasis on meaning is made because it gives learners "an enriched experience of L2 learning in which immediate use of the L 2 produces tangible results, giving purpose and meaning to the L2 learning process" (p.19). Additionally, Byrnes (2002) explores the role of task-based assessment to encourage curricular changes from a form-based normative approach to a language-use and language-meaning orientation. She 
illustrates how those task-based assessment practices can be highly facilitative of that complex goal, pointing out that task and task-based assessment must be contextualized within larger intellectual and educational concerns and must reflect the dynamics of a particular programmatic setting.

Sarani \& Sahebi (2012) present a specific case of students learning vocabulary through literary texts using task-based learning and acknowledge the benefits that this approach had in teaching technical vocabulary, compared to other traditional methods. They claim that these positive results owed to the particularities of the TBA where learners are presented with a task or problem to solve and have a focus on meaning, rather than on language features during performance. Their study provides further exemplification of the terrain we have walked through in our own research experience. It illustrates a way in which the TBL Approach can be used when dealing with literature as to offer an excellent opportunity for students to engage in learning activities that provide meaningful input, following a process where the teacher collaborates and guides, but does not control students' learning process. Instead, he nurtures an adequate learning environment that prepares students for life-long learning.

Locally, Peña and Onatra (2009) propose a series of tasks to encourage high school EFL learners' oral production framed in Willis' (1996) approach. They offer some theoretical considerations concerning the importance of oral skills and explain how the task, as the basic point of organization, generates the language to be used by students. They then contend that language is seen as the instrument necessary to carry out the tasks presented to students. On the other hand, Galvis (2011) asserts that "importing language teaching approaches that are not locally created can be either beneficial or counterproductive, depending on the specific traits of each culture where such approaches would be ultimately implemented" (p. 200). He also supports the use of TBL for contextualizing language teaching and learning, as he points out that "in the case of the Colombian context and the TBL approach proposed in the CEFR, one can observe that teaching by means of processes is an appropriate match culturally speaking because the Colombian culture has been described as a process-oriented culture in several aspects of life, as explained by Foster (2002) and Frechette (2007), in which process takes more importance than immediate results" (p. 200).

From the preceding discussion we can safely assert that in the EFL realm, looking at literature as a useful medium by means of which cultural contents can be shared can be the starting point in triggering students' interest in venturing to use the target language for real communicative purposes. This will undoubtedly call for teachers' ingenuity in designing lessons which are based on works that appeal to students, and which can be chosen by the teacher or by students themselves. In choosing a literary text, however, teachers must always remember what may sound as trite: One enjoys reading better when 
one has a choice in deciding what to read. Isn't this especially true in the case of reading for pleasure, that is, in the case of literature, as it has been defined here? Together with this is the idea that learning, in any field, and particularly language learning, is facilitated by involving learners in hand-on activities; in other words, by having students complete tasks that are meaningful to them. This is the ultimate purpose in implementing the Task-Based Learning Approach in our EFL classrooms, for task-based activities beget language appropriation; language appropriation begets entrance into a new culture; and entrance into a new culture offers students reasons to want to learn more about others.

\section{Method}

The research study was carried out in an EFL context, more precisely, at Universidad del Valle (a large public university in Cali, Colombia). The population sample comprised 26 students in the Foreign Language-English/ French BA Program, who had enrolled English VI, an Intermediate-level course offered in the February - June 2018 academic term, which aims at further developing students' reading and writing skills.

Information was gathered by means of two types of instruments. First, a semi-structured eight-item questionnaire was used to elicit data on students' preferences for reading and writing, of which four were closed-end questions and four were open-end questions. (See Appendix A). Second, an open-end questionnaire or Reading Guide, treated as a series of tasks itself, which they used to channel their reading and complete a literary reading project. (See Appendix B). Students were given the Reading Guide on the first day of class. The purpose of the reading project was explained, together with specific instructions about how to complete it. Then, and along the span of the academic term, individual teacher-student conferences were scheduled weekly, in which the student addressed specific aspects of his work and was advised on how to deal with them. The teacher took notes in each conference and, when necessary, used them for general class discussions which would further help students in getting a clearer grasp of distinct linguistic features, including grammar, syntax, style, vocabulary, sentence structure, and others.

\section{Results}

\section{The semi-structured questionnaire}

We found a whole range of student expectations when registering for a reading and writing course, namely, writing on different text typologies, followed by extensive reading, and study of grammar and mechanics. These 
choices may be telling of two facts: first, that students feel that they come to a writing class to actually put pen to work, and, second, that the reading of different types of texts provides them with models from which they can learn to later imitate a writer's style. Interesting enough, grammar and mechanics instruction appears as necessary or desired contents, as the participants felt that they needed these to attend to some formal features of good writing. This students' awareness of the importance of form was most probably born out of our previous regular class discussions in which we insisted on allotting equal weight to the form and the content of the written text, since form and content constitute its two inseparable dimensions and, thus, they say much about the writer and his product. Therefore, and contrary to what some teachers may think, we contend that even in beginning courses, efforts should be made to instill in students this idea that although the use of correct grammar and proper mechanics does provide for all that is needed to write well, it does play a crucial role in helping the writer convey meaning by adhering to writing conventions.

The participants believed that the role of literature in foreign language learning is an extremely important one, as it provides them with access into other worlds, thus building bridges among people from different cultural backgrounds to enrich learning. In accomplishing this, they feel that opportunities should be offered for them to read and write frequently on what they read, as literary texts flourish in themes most likely to spark their imagination. Hence, the fact that most of the participants in this study enjoy reading literary publications adds to current research findings and to our practice-born belief that using literature as a tool in language teaching results in significant gains in students' learning process, as this type of reading is in consonance with their own likes and interests.

Interestingly enough, and although we have previously said that reading and writing go hand in hand, one thing is a person's reading preference and another different one may be his preference for writing the type of text he likes reading. This explains why, if most of the participants like reading literary texts, only a few of them admit to their writing about literature. We believe that this may be due to the constraints of literary writing which at first may prevent students from venturing to express themselves since, as we have pointed out, there is this confounding idea that the ability to write, especially literature writing, is a gift only a few chosen people possess, an idea coupled with the 110 fact that the participants say that in most of their courses, and independent of their nature, writing is devoted little time, in favor of developing other language skills.

In short, the students' answers show that the key factor in fostering their language learning lies in involving them in tasks and activities in which they have some interest, as these tasks and activities become instrumental in raising their eagerness to perform better and, consequently, make them move to higher 
stages of language proficiency. Based on our own experience, we firmly believe that literature provides myriad opportunities for EFL teachers to help students succeed in meeting their language needs, by planning student interest-based, in-class and outside-class activities.

\section{The Reading Guide}

In an attempt to offer students further opportunities for self-expression, a ten-item, open-ended reading guide was designed as a series of tasks, which was intended to elicit information from students about specific aspects of an English language fiction novel each chose to read. They were required to complete a reading and writing project based on the reading guide, and submit and present their work orally in class. Following is a report of the students' unedited answers to each of the questions in the Reading Guide. (See Appendix B). We will refer to individual students as P1 (Participant 1), P2 (Participant 2), P3 (Participant 3), and so on. Yet, we will account for only some of the students' answers which were selected at random, mainly because of space limitations.

Question 1: What book did you choose to read? Students' choice of novel varied in genres and themes. These included science fiction, historical narratives, social and political advocacy, child rearing, hedonism, and juvenile adventure, just to mention a few. The selections were judged to be representative of individual likes and interest in reading and linguistic abilities. (See Appendix D)

Question 2: What is the significance of the title, as you see it within the context of the story?

Here, P2 maintains that Cell (by Stephen King) is closely related to the development of the story, since it is because of cell phones that people turn into zombies. He points out that "This is how the apocalypse starts ... I see that the word cell rhythms with hell, which is exactly the situation the characters of the story go through."

What is apparent here is this student's worries for the fate of those who do wrong and how their actions epitomize a society lured and subsequently trapped by technology, actions conducive to hell.

Question 3: Theme. Several themes may be dealt with in this book. List and explain them.

When addressing this question, P3 states that some of the themes that Behind the Beautiful Forevers (by Katherine Boo) deals with include poverty, corruption, economic inequality, life, death, and hope. For this student, "Finding all of these issues in a small community which nobody wants to 
acknowledge is something we must know and think about. Injustice, fear, and despair are very common among the characters of the story which lead some of them to committing suicide." Interesting enough, this student warns that "Although this story tells us about a big problem in India, its point is not only to make people care about Abdul, Manju, Kekahshan, or Asha's situation, for example, but also make people aware of and care about those other people that have to struggle in life, those we never noticed, even if they are around us. Therefore, one of the most remarkable things in Behind the Beautiful Forevers is the way the book connects a social problem with you, the reader."

As seen, this student has used facts from the narrative and related them to a wider context: the social conditions many people around the world live in. In closing up, P3 has further used all this information to share her personal stand on the issue of poverty, by stating that "It [the story] makes you know and feel that it is real people who are suffering," something the student tugs as an awful feeling.

In dealing with the themes she actually found in her choice of book, P4 writes that friendship finds its way throughout Looking for Alaska (by John Green), as it is the theme she feels mostly touched by. She lets us know that "friendship appears from its very beginning to the last meaningful moments of the story as a recurrent element that leads to an interesting drama. In the story, one of the main characters arrived to a boarding school where he has no acquaintances and thus, he is required to make true friends - in order to survive and enjoy his junior year-given the fact that there were enemies to face, authorities to obey, and joyful academic moments to share." She further makes a connection between the experience the main characters in this story go through and what the main two characters in Wills Hurvin.'s A Time for Dancing, Samantha and Juliana, lived as school friends. She points out that " Just as Sam and Jules build this unbreakable bond they lived by — one that outlived Jules - the type of relationship Miles was able to establish at school tells a lot about the human nature, since we all need the presence and the support of others, regardless our degree of independence."

It is worth noting how this student uses background knowledge to make the link among her vision of friendship, what she learned from one of her previous reads, and what she considers is a trait of human beings.

112 Question 4. The plot (a summary of the story). Do not recount the whole story. Focus on the main events, instead.

In her answer to this question, P23 provided the basic information required by readers to get a grasp of the story told in Ties that Bind, Ties that Break (by Lensey Namioka), as a way to trigger their interest in reading it. In other words, she has been cautious not to spoil future readers' desire to have their own personal encounter with what this China and its people were like. 
Set in 19th Century China, Ties that Bind, Ties that Break tells the story, in retrospect, of the daily struggles that Ailin, the main character, goes through which had their origin in the social custom of girl foot binding throughout the imperial years. But she is lucky to escape this fate, thanks to the relationship she and her family establish with an American family, the support she receives from her father, and the courage she gathers from one of her school friends. Eventually, she moves to the United States where she spouses a businessman, actually a restaurant owner, with whom she starts a new life.

This question had the participants resort to their synthesizing skills, in order to prevent them from just recounting the sequence of the events, sprinkling it with minor details which they judged to be essential, and from using parts of published reviews as if they were their own work. However, the guidance they received throughout the process of putting together their project proved useful in helping them see the forest without necessarily stopping to account for every tree in it and prevented them from incurring plagiarism, which at this time all of them acknowledged as being a blatant intellectual crime.

Question 5. Main characters, what they want to accomplish, how they go about accomplishing their goal(s), and whether they succeed in doing it. Which of them do you identify most with? Why? Which of them do you identify the least with? Why?

This question was intended to elicit information on whether the student built rapport with a certain main character in the story, as it is usually this reader-character empathy that determines whether the former feels moved to continue reading and intrigued about the unfolding of the events triggered by the latter, which, in turn, influences the reader's liking or disliking the story. This is, precisely, what happens with P5, who finds herself deeply touched as a result of her having read Sula (by Literature Nobel laureate Toni Morrison):

I identify the most with Sula and Nel. I have always been curious about life; I want to experience everything, at least once. I do not like the idea of waiting for a person to love me, meaning that my life would be complete just when that happens. Like Sula and Nil, I had the feeling that my life was really good when my best friend and I were together, laughing and talking all day long. Unfortunately, I also realized that even friendship has an end and that distance can affect the way you treat a person so badly. Nevertheless, although I constantly seek independence, by attempting to realize all my "feminist" ideals, I cannot fool anyone, since I am too desperate for love. I have a very conventional side in my way of finding someone to spend the rest of my life with. I still have my prospect. Likewise, Nel said that hell was not doing the same thing over and over again, but it was change. Changes scare us, because we are 
blind to them. I enjoy spending all day long at home, watching movies and reading a book. I do not need crazy things in my life to be happy. I, too, seek tranquility. I think that happiness is the ultimate combination of Nel and Sula: they think they are no longer similar, but they both look for the same outcome.

This student opens up to us, letting us know who she is and why she likes and identifies with Sula and Nel, because she is pretty much like them. Then, she goes on to tell us what she thinks of three other characters and why.

I identify the least with Eva, Hannah, and Helene, the ones who raised Nel and Sula. They are not that different; they are traumatized in some way. But this is not why I do not identify with them, rather I consider them as the model I would not follow. I constantly care and think about the ones around me. I wish them nothing but good. As I was reading these three people's lives, I decided that no matter how bad an experience could be, I would not treat anybody badly, especially the ones I love the most.

Again, P5 has scrutinized these three characters' lives, looked into her own life, and made a resolution: She wants to be true to herself; she is goodness and so, this is what she wants to project in her relationship with others.

Question 6. Part or parts of the book you find particularly important. That is, the one part of the story you feel touched by. Quote some passages, indicating the corresponding page number(s). Why is this important to you?

In dealing with this question, this is what P25 singles out, after reading 1984 (by George Orwell): "The choice for mankind lay between freedom and happiness, and that, for the great bulk of mankind, happiness was better." (p. 153). Next, he explains what this means to him:

I believe that this quote captures what we are living today. It is unbelievable that this was written in 1948. This represents our surrender; we are giving up freedom to obtain "happiness", or, at least, what society defines as happiness. We are giving up our time and life by working to obtain material goods that are supposed to bring us security and joy, but in reality we don't even need those things. What we need is freedom and strength to escape society. 
What this student has selected as being meaningful to him is based on his understanding of how social systems work, that is, what humans are faced with, as part of the society they live in. The student's position on the issue of freedom and happiness is clearly explained by his choosing freedom over happiness and stating that courage begets freedom.

We believe that in a course, and especially in a reading and writing course, after students have been graded, grades have been reported to the Registrar's Office, and the academic term is over, what remains in the students' mind is what they did in that course and how significant it is for them as individuals. We venture to assert that one instance of this significance is what they read, which actually plays a role in maintaining or in altering their vision of the world they live in.

Question 7. Linguistic aspects. How do you judge the writer's style? Explain and quote passages to support your claim.

In connection with this, P24, presents us with this quote from Kinshu: Autumn Brocade (by Miyamoto Teru): "East Maizuru was indeed a sleepy town on the northern border of the Kyoto region, facing the Sea of Japan. Snow in winter, humidity in summer, and the other seasons marked only by the leaden skies and the thick clouds, sparse traffic, and dust-laden winds from the sea" (p. 30). Then, this student is quick to let us know what this means to him: "A description like this one makes you feel as if you were actually in the scene. It makes you feel the cold of winter, the suffocation of summer, and see the beautiful brocades of autumn and spring, thus providing you with a brief, yet a substantial description of everything a foreigner should know about this region."

It is true that, as readers, we tend to favor certain writers over other ones, which is a feeling born out of our judgment concerning the way, means, or techniques the author uses to convey his message. Among others, it is the writer's choice of vocabulary, syntactic constructions, sentence structure, paragraph technique, the message itself, and the distance he takes from his readers that set some writers apart from others. Generally speaking, our participants are not an exception to this, when expressing their preference.

Question 8. Write a letter to the author in which you express your feelings about his/her book. You may want to focus on a particular aspect of this book, including one or more characters.

The Students' answers to this question show their engagement with different aspects of the story they read and depict meaningful real-life interactions, like in the case of the rapport P1 established with Ooji Kouji, author of High speed. Below is her letter to him: 
Dear Mr. Kouji:

I'm not good with words. I'm awkward when expressing myself, especially when I want to talk to someone whose work has been well received. I admit that, at first, I found the title and the premise to be a bit cheesy, but as I kept reading, I found myself with a slice-of-life story that in certain aspects reminded me of my childhood: my friends, the routine of walking back home and then meeting with them again to do something together. It also made me reflect on some aspects of my childhood and the relationship with friends. At first, Haru didn't like Rin and wanted to stay away from him as much as possible, because he couldn't understand how someone else could blend with the water as well as Haru himself. It reminded me of how I used to scoff at kids I didn't like. But in the end everything works out for the group and Haru manages to get along with Rin. It makes me nostalgic, wanting to go back to my hometown and see if there are some of my old friends there.

Another aspect that I liked and felt identified with is that I'm afraid of water because I don't know how to swim, unlike Makoto, who is afraid but still knows how - and likes - to swim. I hope that, one day, I can overcome my fear and learn how to swim, too.

As I mentioned, I'm not really good with words, but I wanted to tell you that your book has brought me good memories from my childhood, something really hard to deal with.

Sincerely,

P1]

As can be said that the power of books lies in this unique likelihood, they offer to take readers not only to outer worlds, but also to their inner selves. In doing so, books fulfill their transformational mission. Indeed, nobody comes out being the same after reading a book, regardless of the type of connection a reader might have made with the story and its author. This is clearly illustrated in P1's letter to Mr. Kouji. Thus, the story has influenced her in such a way, that she sees it as a flashback into her own life, her childhood, a revival of moments she shared with some of her friends. Eventually, she is filled with nostalgia, to the point that she admits to her wanting to go back to her hometown, expecting to reencounter her acquaintances.

Question 9. Besides new vocabulary, what did you learn as result of your having read this book? Would you recommend other people to read this book? What people?

It is in our human nature to want others to have what has been good for us and wish others avoid what has caused us harm. It seems that the same happens with our reading experiences. Hence, we praise authors whose work we have enjoyed and, conversely, we use derisive language to refer to those authors and their work we have not found ourselves connected with. The former is what P6 shares about her experience in reading The Kite Runner, by Khaled Hosseini: 
I learned so many things. I learned about the Afghan history, foreign interventionism, and discrimination in Afghanistan. I also learned that Afghans use the word hazara to refer to people who belong to an ethno-linguistic minority group. Still other aspects I learned about are the atrocities inherent to the war and violence and sexual abuse in Afghanistan. Therefore, this book gave me a different vision of Afghanistan and its problems and what people have to live every day there. Likewise, I learned that you have to keep up with your life, be happy no matter the problems you have to face, give the best of yourself, and not give up.

As whether this student recommends this book, she states the following:

I recommend other people to read this book. It is written for a wide audience (adults and teenagers). It is about real facts, situations that happened and are still happening at this moment, which we don't see and we don't know much about. Besides, it is the other side of the story, narrated by someone who knew that world before and after the war. Thus, it gives us another perspective of the story.

It is interesting to read how much this student has taken from the story. Thus, and judging from the student's words, author Hosseini has provided her with a mini course on the history of Afghanistan, a course that regardless its brevity, still accounts for the past and present of this territory and its people. Again, this is what reading can do for us: let us shake hands with people we never thought we would ever meet.

Question 10. Make a piece of art that, in your opinion, represents the story being told in the book or part of it. Bring your work to class and be ready to talk about it.

This question was intended to offer students an opportunity to try their artistic skills and exert their creative and imagination power by freely expressing themselves aesthetically. An additional purpose of this task was to have students set up an exhibit of their work for the student population, the teaching and the administrative staff of the School of Language Sciences, and the general public interested in attending our Summer Language festival, which is customarily held as an end-of- term activity jointly prepared by students and teachers.

The pieces of art presented by students included collages, photographs, sculptures, paintings, scale models, drawings, poems, and lyrics which students sang in the event.

The exhibit was set up in one the corridors of the School. Each piece of art was appropriately identified by indicating the title of the book it was based 
on, its year of publication and publisher, its author, the student's name, and the technique used to produce it. Each student answered questions from visitors about the work, which resulted in an enriching interaction between attendees and novice artists. (See Appendix C).

\section{Discussion}

The use of literature has been recognized as being of much value for second language students and especially for foreign language students, as it depicts language in different real communicative contexts, triggers students' motivation, and serves as a bridge between authors and their society and readers.

The studies reviewed here reveal that literary texts constitute authentic materials that can be used to meet students' best interests, namely the development of their reading and speaking skills. These studies emphasize the need to exploit these materials by designing learner-centered lessons, particularly by implementing the Task-Based Approach in which students learn by doing. Our study corroborates previous findings, as participants were highly motivated to read the novel they chose, complete the different tasks they were assigned, and present their work orally in class. Equally revealing of students' linguistic progress was the fact that they showed a genuine interest in sharing their work with the public attending the Summer Language Festival by preparing and delivering a mini lecture about their findings.

\section{Conclusion}

We have delved into the use of literature in offering EFL students opportunities to enhance their learning process. Thus, when seen as a tool rather than an end, literature can trigger learners' motivation and offer them unique instances for them to deal with authentic texts that depict the life of people, in terms of their religious, political, economic, and social beliefs, as well as other traits associated with their lifestyle.

Our findings corroborate previous findings which show that even if students' active participation in their learning process is vital, they are not

118 solely responsible for the success of this process. Therefore, in attending to the participants' needs, the weekly teacher-student conferences we scheduled proved useful in helping individual students successfully deal with their reading and writing concerns resulting from their involvement in the different tasks they were to cope with. Likewise, these conferences helped most students build increasing confidence in their oral production, as compared with a certain lack of easiness they showed in individual classroom presentations, which we 
think was due to their relatively scarce vocabulary range, the type of topics they knew little about, and the degree of formality inherent to the texts. However, we believe that future English teachers should be conversant with a plethora of topics, not only with that which interests them. Thus, these findings add to the evidence that teachers have a crucial role to play in choosing materials and designing task-based, student-centered activities that can best meet students' needs. In doing this, language teachers need not be literature graduates. All they need is a liking for literature and willingness to try their ingenuity. In our study, participants felt challenged and their motivation for reading, writing, and speaking increased, as shown in what they did. This is because, typically, reading materials are chosen by teachers, which not always match students' reading likes. For example, some of the materials we used to develop course contents dealt with topics in economics, engineering, biology, politics, religion, and gender, which did not appeal to all of the students. Consequently, students showed difficulties in understanding vocabulary and in writing and speaking about these topics. Conversely, giving students the opportunity to choose a book to read was important in raising their motivation to read, write, and speak about their story, and although the written report each submitted needs additional work on revision and editing to fully reflect writing conventions, each shows features of good writing as it is authentic, depicts the author's voice and his knowledge of the world, and speaks to a certain audience. Therefore, it is hoped that these findings contribute to raising awareness of some of the factors that teachers should take into account when planning activities to respond to their students' needs in similar contexts. 


\section{References}

Ayo, O. (2003). Developing EL2 Learners' Communicative Competence through Literature in English. In Oyeleye, \& Olateju (Eds.), Readings in Language and Literature (pp. 127-136). Ile-Ife: Obafemi Awolowo University Press Ltd. Nigeria.

Brontë, C. (2008). The Professor. Project Gutenberg.

Byrnes, H. (2002). The Role of Task and Task-Based Assessment in a Contentoriented Collegiate Foreign Language Curriculum. Language Testing, 19 (4), 419- 437.

Collie, J., \& Slater, S. (1987). Literature in the Language Classroom. Cambridge: Cambridge University Press.

Collie, J., \& Slater, S. (2005). Literature in the Language Classroom. (5th Ed.). Glasgow: Cambridge University Press.

Duff, A. \& Maley, A. (1991). Literature. Oxford: Oxford University Press.

Ellis, R. (2003). Task-Based Language Learning and Teaching. Oxford: Oxford University Press.

Galvis, H. (2011). The Common European Framework, Task-Based Learning, and Colombia: Crossroads for an Intercultural Collision or a Path under Construction for Improvement? HOW 18, 198-209.

Garzon-Duarte, E. (2007). Inquiry Process through Literature in the EFL Classroom: A Broad Path to Work on Critical Thinking. How, 14, 81-88.

Gomez-Rodriguez, L. (2013). Enhancing Intercultural Competence through U.S. Multicultural Literature in the EFL Classroom. Folios, 38, 95 -109.

Gower, R., \& Pearson, M. (1986). Reading Literature. London: Longman.

Hill, J. (1986). Using Literature in Language Teaching. London: Macmillan.

Ihejirika, R. (2014). Literature and English Language Teaching and Learning: A Symbiotic Relationship. English Language Teaching, 7 (3), 85-90. Canadian Center of Science and Education.

Kooy, M., \& Chiu, A. (1998). Language, Literature and Learning in the ESL Classroom. English Journal, 88 (2), 78-84.

Lazar, G. (1993). Literature and Language Teaching: A Guide for Teachers and Trainers. Cambridge: Cambridge University Press.

Nunan, D. (2004). Task-Based Language Teaching. Cambridge: Cambridge University Press. 
Peña, M., \& Onatra, A. (2009). Promoting Oral Production through the Task-Based Learning Approach: A Study in a Public Secondary School in Colombia. Profile, 11 (2), 11-26.

Sarani, A., \& Sahebi, L. (2012). The Impact of Task-Based Approach on Vocabulary Learning in ESP Courses. English Language Teaching, 5 (10), 118-128.

Savvidou, C. (2004). An Integrated Approach to Teaching Literature in the EFL Classroom. The Internet TESL Journal, 10 (12), retrieved from: http:// iteslj.org/Techniques/Savvidou-Literature.html

Short, M. (1996). Exploring the Language of Poems, Plays and Prose. New York: Longman.

Skehan, P. (1996). A Framework for the Implementation of Task-Based Instruction. Applied Linguistics, 17 (1), 38-62. http://dx.doi.org/10.1093/ applin/17.1.38

Skehan, P. (1998). A Cognitive Approach to Language Learning. Oxford University Press.

The American Heritage Dictionary of the English Language (2015), fifth edition. Houghton Mifflin Harcourt.

Torres, G. (2014). The Task-Based Syllabus: Promoting L2 Acquisition and Learner Empowerment in an EFL Classroom. International Journal of Education, 6 (2), 11-23.

Valdes, J. (Ed.). (1986). Culture Bound. Bridging the Cultural Gap in Language Teaching. Cambridge: Cambridge University Press.

Violetta-Irene, K. (2015). The Use of Literature in the Language Classroom: Methods and Aims. International Journal of Information and Education Technology. 5 (1), 74-79.

Widdowson, H. (1983). Talking Shop: On literature and ELT. ELT Journal, 37 (1), 30-35.

Willis, J. (1996). A Framework for Task-Based Learning. Harlow, UK: Longman.

Willis, D., \& Willis, J. (2007). Doing Task-Based Teaching. Oxford: Oxford University Press. 


\title{
Authors
}

*Argemiro Arboleda-Arboleda holds a B.A in Modern Languages from Universidad del Valle (Cali, Colombia) and an M.A in Education (TESOL) from University of Kansa (United States). He is currently an English Teacher at Universidad del Valle. His research interests include writing as a foreign language, editing and translations.

ORCID: http://orcid.org/0000-0001-9822-9409

\begin{abstract}
Angela Castro has a B.A in Modern Languages, a Specialization in Pedagogy of Reading and Writing, and a M.A in TESOL. She is a third-year $\mathrm{PhD}$ student at Universidad del Valle, and a professor at Universidad del Cauca. Her research interests include literacy studies and intercultural communication.
\end{abstract}

ORCID: http://orcid.org/0000-0001-6675-0937 


\section{Appendix A: Questionnaire}

Please answer the following survey to the best of your knowledge. This information will allow us to make a needs analysis and improve our teaching practices. You do not need to provide your name.

\begin{tabular}{|c|c|c|c|c|c|}
\hline 1 & $\begin{array}{l}\text { What components do } \\
\text { you expect to find in a } \\
\text { writing class? }\end{array}$ & & & & \\
\hline 2 & $\begin{array}{l}\text { How relevant } \\
\text { is literary work } \\
\text { (literature) in your } \\
\text { English learning? } \\
\text { Why? }\end{array}$ & & & & \\
\hline 3 & $\begin{array}{l}\text { How often do you } \\
\text { read? Why? }\end{array}$ & $\begin{array}{l}\text { Less than } \\
1 \text { hour per } \\
\text { day }\end{array}$ & $\begin{array}{l}1 \text { hour per } \\
\text { day }\end{array}$ & $\begin{array}{l}2 \text { hours per } \\
\text { day }\end{array}$ & $\begin{array}{l}\text { More than } \\
2 \text { hours per } \\
\text { day }\end{array}$ \\
\hline 4 & $\begin{array}{l}\text { How often do you } \\
\text { write? Why? }\end{array}$ & $\begin{array}{l}\text { Less than } \\
1 \text { hour per } \\
\text { day }\end{array}$ & $\begin{array}{l}1 \text { hour per } \\
\text { day }\end{array}$ & $\begin{array}{l}2 \text { hours per } \\
\text { day }\end{array}$ & $\begin{array}{l}\text { More than } \\
2 \text { hours per } \\
\text { day }\end{array}$ \\
\hline 5 & $\begin{array}{l}\text { What kind of texts do } \\
\text { you read? }\end{array}$ & Literary & Academic & Informative & Other \\
\hline 6 & $\begin{array}{l}\text { What kind of texts do } \\
\text { you write? }\end{array}$ & Literary & Academic & $\begin{array}{l}\text { Personal } \\
\text { (lists, } \\
\text { reminders, } \\
\text { etc.) }\end{array}$ & Other \\
\hline 7 & $\begin{array}{l}\text { List the factors that } \\
\text { restrain you from } \\
\text { reading and writing } \\
\text { more. }\end{array}$ & & & & \\
\hline 8 & $\begin{array}{l}\text { What kinds of } \\
\text { activities would you } \\
\text { like to see in this } \\
\text { course? }\end{array}$ & & & & \\
\hline
\end{tabular}




\section{Appendix B: Reading Guide}

Directions. Submit your answers to the questions below, about the novel you chose to read, and prepare a twenty-minute presentation to share them with the rest of the class. Use your summary, paraphrase, and quotation cards only for reference, as this is not intended to be a reading session.

1. What book did you choose to read? (title of the book, year of publication, editorial house, number of pages)

2. What is the significance of the title, as you see it within the context of the story?

3. Theme. Several themes may be dealt with in this book. List and explain them.

4. The plot (a summary of the story). Do not recount the whole story. Focus on the main events, instead.

5. Main characters. Which of them do you identify most with? Why? Which of them do you identify the least with? Why?

6. Part or parts of the book you find particularly important. That is, the one part of the story you feel touched by. Quote some passages, indicating the corresponding page numbers. Why is this important to you?

7. Linguistic aspects. How do you judge the writer's style? Explain and quote passages to support your claim.

8. Write a letter to the author in which you express your feelings about this book. You may want to focus on a particular aspect of the book, including one or more characters.

9. Besides new vocabulary, what did you learn as result of your having read this book? Would you recommend other people to read this book? What people?

10. Artwork. Make a piece of art that, in your opinion, represents the spirit of the story being told in the book you read, or part of it. Bring your work to class and be ready to talk about it. 


\section{Appendix C. Some of the pieces of artwork submitted and exhibited by students}

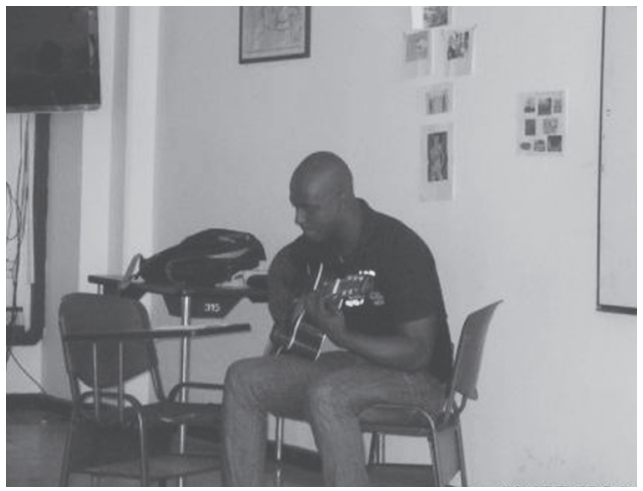

1. Student performing the song he wrote, based on They Say Love is Blind (Kate Halleron).

Link to his video: https://youtu.be/wh_x_WujzLs. Lyrics below.

\section{THEY SAY LOVE IS BLIND}

He was blinded in the war and never again saw the sunshine

Or the moon that was surrounded by stars at night

An inspected trip on train - he didn't know that it would change

The course of his life - with a surprise

\section{BRIDGE}

His ex-wife appeared, but now he had a new love

Two women who loved the same man

\section{CHORUS}

\section{THEY SAY LOVE IS BLIND}

He fought against time and divided his heart

THEY SAY LOVE IS BLIND

The civil war took a part of his life

THEY SAY LOVE IS BLIND

He was a brave man who never gave up

THEY SAY LOVE IS BLIND

He couldn't see, but he could still love. 


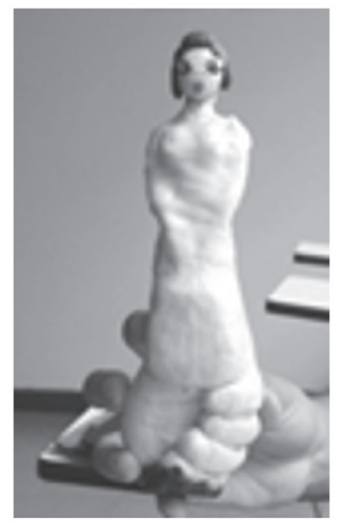

2.Piece based on Ties That Bind, Ties That Break (Lensey Namioka)

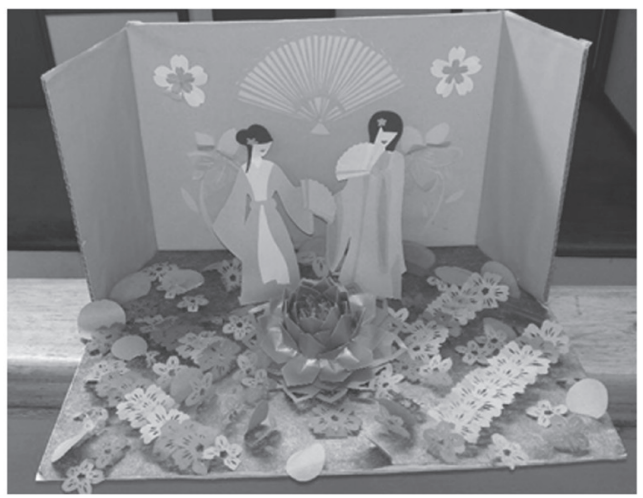

3.Piece based on Kinshu:

An Autumn Brocade (Teru Miyamoto

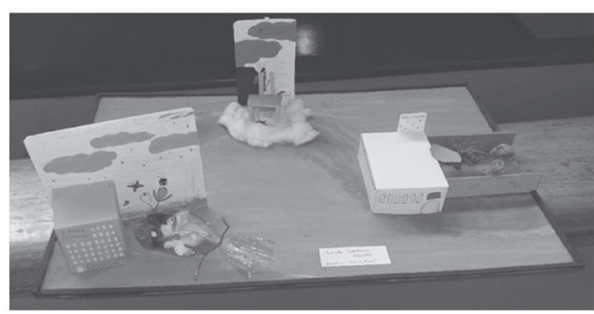

4. Piece based on The Professor (Charlotte Bronte)

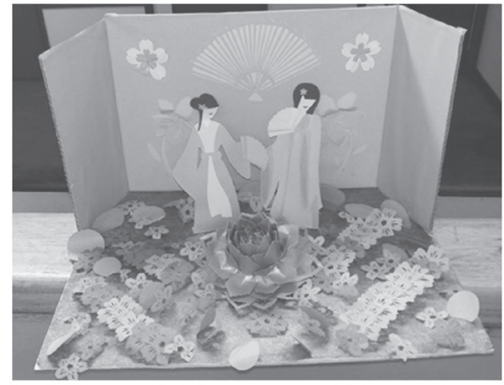

5. Piece, based on Kinshu: An Autumn Brocade (Teru Miyamoto) 


\section{Appendix D: List of some of the novels that the participants read}

Brontë, C. (2008). The Professor. Project Gutenberg.

Cline, E. (2011). Ready Player One. Crown.

Green, J. M. (2005). Looking for Alaska. Dutton Juvenile

Halleron, K. (2012). They Say Love is blind. Pepper Pace.

Hosseini, K. (2003). The Kite Runner, Riverhead Books

Hurwin, W. D. (1997). A Time for Dancing. Puffin Books.

King, S. (2006). Cell. Scribner.

Kouji, O. (2013). High Speed. Kyoto Animation

Namioka, L. (1999). Ties That Bind, Ties That Break. Random House.

Miyamoto, T. (2007). Kinshu: Autumn Brocade. New Directions.

Morrison, T. (2002). Sula. Pinguin Random House.

Orwell, George. (1949). 1984. Harvill Secker.

How to reference this article: Arboleda-Arboleda, A., \& Castro-Garcés, A. Y. (2019). Fostering Language Learning in the University EFL Classroom through Literature: A TaskBased Approach. GIST - Education and Learning Research Journal, 19, 101-127. https://doi. org/10.26817/16925777.706 